\title{
The economic cost of seabird bycatch in Argentinean longline fisheries
}

\author{
PATRICIA GANDINI and ESTEBAN FRERE
}

\begin{abstract}
Summary
Seabird mortality in longline fisheries is believed to be an important cause of the reductions in many seabird populations worldwide, and results in reduced fishing efficiency and economic losses for fishing companies. We estimated the economic cost of not using seabird bycatch deterrents in Argentinean longline fisheries, with the intention of encouraging adoption of mitigation measures in those fisheries. We conducted the study in the Argentine ling Genypterus blacodes and Patagonian toothfish Dissostichus eleginoides fisheries from 2001 to 2006 on three fishing vessels. Data on the incidence of seabird bycatch were collected by seabird observers specially trained in seabird identification and data on the catch rates of target species, cost of bait and fish were provided by the fishing company, supervised by Federal Inspectors from the Provincial Fisheries Agency. To estimate the bait loss, we set lines both with and without the use of deterrents (streamer lines, night setting and strategic discharge of offal) in both fisheries. Seabird bycatch varies temporally and geographically, so to estimate economic losses using deterrents in each fishery, we used different bycatch rates/10oo hooks registered for different periods and fishing areas. Bycatch rates in the absence of deterrents were two birds/10oo hooks and 1.53 birds/10oo hooks for the Patagonian toothfish and ling fisheries, respectively. These rates equate to the loss of more than 1.5 and 2 million dollars over a 1o year period for each fishery. When estimations are made with lower mortality rates, economic losses declined abruptly and were in the order of hundreds of dollars/fishing trip, for the same period of time. Results show that using deterrents, long term profits for the fishing company increase at a considerably high rate (the decrease in monetary loss is an order of magnitude), and the mortality of seabirds decreases by the same proportion (CPUE of seabirds decreases from tens of thousands to a few hundred). In these fisheries, the use of mitigation measures that reduce bait loss and seabird mortality represents a win-win situation with benefits to conservation and fishing companies.
\end{abstract}

\section{Introduction}

Seabird mortality is a serious conservation problem in many longline fisheries around the world (Croxall et al. 2012). Typically, during the longline setting process, baited hooks area available to seabirds and they may become hooked drown. A few birds may also be hooked and killed during the hauling process. Mortality in longline fisheries is believed to be an important cause for the reductions in many seabird populations worldwide, especially albatrosses and petrels (e.g. Robertson and Gales 1998, Phillips et al. 2006, Poncet et al. 2006).

In addition to reducing seabird populations, baits scavenged from longlines result in reduced fishing efficiency, as each bait lost is one less available to catch fish. For example, in the Norwegian torsk Brosme brosme and ling Molva molva fishery an estimated 13-14\% of baits are removed from hooks by seabirds (Løkkeborg and Robertson 2002). Clearly, bait loss can result in significant economic loss to fisheries. However, bait loss can be reduced by use of appropriate deterrents (Løkkeborg 2001, Bull 2007, Løkkeborg 2008), although in many fisheries compliance with requirements to use such 
deterrents in the absence of incentives can be problematic (e.g. Melvin et al. 2001) and especially where adoption is voluntary or controls are ineffective. Thus, in order to encourage fishermen to adopt seabird bycatch deterrents it is necessary to highlight the economic cost of bait loss.

In Argentina, longline fishing commenced in the early 1990s, targeting hake Merluccius hubbsi and Argentine ling Genypterus blacodes on the continental shelf and Patagonian toothfish Dissostichus eleginoides in deeper waters off the Patagonian shelf. In 1999 these fisheries combined landed 10,000-12,000 tones which were valued at about US\$80 million (Gandini and Frere 2001). The Patagonian shelf is also an important foraging area for seabirds (BirdLife International 2004), especially the Black-browed Albatross Thalassarche melanophrys (Gales 1998). Not surprisingly, interactions between the Argentine ling (Kingclip) and Patagonian toothfish fisheries and seabirds have been high, with an estimated 2,479 Black-browed Albatrosses killed in the three year period 1999-2001 (Favero et al. 2003). Considerable bait loss to seabirds (in the absence of deterrents or when they are not set up properly), and associated reduction in the quantity of fish landed, could also be expected in these fisheries.

This paper describes a study to estimate the economic cost of not using seabird bycatch deterrents in Argentinean longline fisheries. Since the use of mitigation measures was at the discretion of the captains, the objective was not to present information on the effectiveness of different mitigation measures, as such, but to provide an estimation of the economic benefits of using these measures. Although mitigation measures are currently required by law in the Argentinean longline fisheries (Federal Fishing Council resolution CFP 08/2008), mitigation measures were not mandated by government during this study period.

\section{Methods}

\section{Fishing operation}

The research was conducted in the Argentine ling and Patagonian toothfish fisheries from 2001 to 2006 on fishing vessels Fuji, Stella and Marunaka, which are owned by Argenova S.A. The three industrial longline vessels are more than $40 \mathrm{~m}$ in length and very similar to each other. The vessels were equipped with Mustad (autoline) bait setting and hauling equipment. The vessels used $11.5 \mathrm{~mm}$ diameter longline with hooks placed $1.2 \mathrm{~m}$ apart on snoods of $0.4 \mathrm{~m}$ in length. The mainline was usually $10 \mathrm{~km}$ in length and sets were typically 20,000 hooks (Gandini and Frere 2006). Hooks were baited with squid Illex argentinus. Settings took $3^{-5}$ hours to complete, while hauling took $3^{-10}$ hours. Lines were left in the water for up to 16 hours before hauling commenced. Fish were processed as they came onboard and the offal (guts, heads and tails) was discarded into the ocean (for more details see Seco Pon et al. 2007). Data on the incidence of seabird bycatch was collected by seabird observers specially trained in seabird identification for this project, i.e. observer data collected by national observer programme were not used. Data were collected through a special agreement between Argenova S.A. and the Universidad Nacional de la Patagonia Austral. Observers focused on recording seabird information and they were monitoring both setting and hauling operations during all the studied fishing trips $(n=18)$. Data on the catch rates of target and non-target fishes were provided by the fishing company, supervised by Federal Inspectors from the Provincial Fisheries Agency. To estimate the bait loss from bycatch we set lines both with and without the use of deterrents in both fisheries. Deterrents used included the setting of longlines at night, the use of a single bird scaring streamer line and strategic deployment of fish waste. All the deterrents were used simultaneously in all the settings where mitigation was used.

\section{Seabird deterrents}

The streamer line had a total length of $100 \mathrm{~m}$, was attached to the vessel at a point $7 \mathrm{~m}$ above the sea surface and towed an object (usually a buoy) at its seaward end to create drag and stability. 
Each branched streamer consisted of two strands of $1 \mathrm{~m}$ long brightly coloured plastic. The same design of streamer line was used during the study.

In some vessels the processed fish (heads, stomachs, livers, etc) were discarded on the same side of the hauling bay, attracting thousands of birds to the area where the hooks were hauled. The strategic discharge of offal from processed fish consisted in the discard of offal on the opposite side of the vessel to the hauling bay, during hauling and afterwards and avoiding discharge during setting.

Night setting and minimal use of deck lights diminish seabird attraction to fishing vessels. While the Ling fishery habitually sets gear at night, the toothfish fishery sets gear during the day. Therefore, reduced use of deck lights and night setting were introduced accordingly.

\section{Estimating bait and economic loss}

Bait loss to seabirds and economic loss was estimated using the following data:

(a) Total number of hooks deployed by fishing trip,

(b) Total number of hooks observed,

(c) Total number of birds killed during setting,

(d) Total number of fresh baits found in seabird stomachs,

(e) Bait weight. Each piece of bait weighed approximately $100 \mathrm{~g}$,

(f) Cost of bait (2005) Bait cost US\$ 1,80o per ton. We used 2005 because was the only one available from the company.

(g) Processed catch, the average weight of fish caught/hook (g),

(h) Value of lost fish (US\$/tonne). This was calculated as the number of lost baits multiplied by the average of fish caught per hook ( $\mathrm{g}$ ) multiplied by the value of the target fish. We assumed that a seabird caught or bait taken corresponds to a lost fish,

(i) Total loss for the company. This was estimated assuming each vessel made five fishing trips per year.

We assumed that a seabird caught or bait taken corresponds to one lost fish. That assumes that fish simply do not swim up the longline to find another bait. We also assumed that all the hooks were baited successfully by the autobaiter.

Seabird bycatch varies temporally and geographically (Gandini and Frere 2006, Gomez Laich et al. 2006), therefore to estimate economic losses using deterrents in each fishery, we used different bycatch rates/10oo hooks registered for different periods and fishing areas. Because the number of birds killed was high when no deterrents were used we only have data of complete fishing trips with no deterrents during spring for each fishery. To estimate the bait loss from bycatch, we only used birds killed during settings because birds caught during hauling does not affect fishing efficiency. Anyway, during our study period only one bird was caught during hauling.

\section{Results}

During the study a total of 166 stomachs collected from Black-browed Albatrosses and Whitechinned Petrels Procellaria aequinoctialis were examined. Since, the modal number of fresh baits in the stomachs of these birds was four (range 1-6), we considered that at least five baits were stolen by a seabird before it was killed (Figure 1 ).

The economic cost of bait loss without the use of deterrents is shown in Table 1. Mean mortality rates in the absence of deterrents were 2 birds/10oo hooks and 1.53 birds/10oo hooks for the Patagonian toothfish and Ling fisheries, respectively. These rates equate to the loss of more than 1.5 and 2 million dollars over a 1o year period for each fishery (Patagonian toothfish value: US\$ 18,00o/tonne; Ling: US\$ 4,80o/tonne). When estimations are made with lower mortality rates, economic losses declined abruptly but were still in the order of hundreds of dollars/fishing trip, for the same period of time (Table 1 ). 


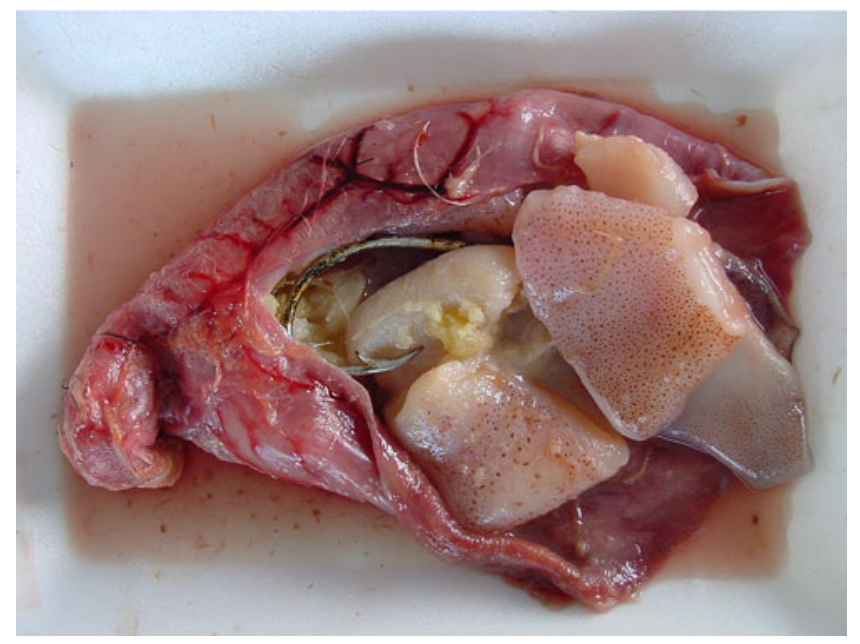

Figure 1. Baits (squid) in a Black-browed Albatross Thalassarche melanophrys stomach.

\section{Discussion}

Longline fishing has raised concern because of the high levels of interactions with non-target species (Brothers et al. 1999, Tasker et al. 2000, Lewison et al. 2004, Dulvy et al. 2008). With respect to seabird conservation it is clear that even low mortality rates can cause serious decreases in seabird populations, as their life-history characteristics cause them to be especially vulnerable. Considerable time and effort has been put into finding solutions to the problem (Melvin and Parrish 2001, Melvin et al. 2004, Dietrich et al. 2008). For their part, in South America and some other regions, fishermen have been reluctant to acknowledge that significant bait loss occurs and consequently have been reluctant to change fishing operations due to seabird interactions with gear. Few previous studies have demonstrated the increase in profits associated with the use of measures that reduce bait loss to seabirds. Løkkeborg (2001) showed a significant increase in catch rates of target fish species for longlines set when using deterrents compared to the control without mitigation measurements.

In our win-win case study, voluntary use of mitigation measures was included during almost all our studied fishing trips between 2001 and 2006, with the exception of our controls. All data were obtained under agreement with the fishing company which worked in close collaboration with the trained observer. Results suggest that using deterrents during line setting and hauling operations, or when probability of seabird capture is known to be high, will lead to long-term profits that are an order of magnitude higher for a fishing company. High bycatch probability has been documented to occur during moonlit nights (Gandini and Frere 2006), daylight hours or when high densities of seabirds are following the vessel. As long-term profits increase, seabird mortality decreases by a similar proportion, i.e. CPUE of seabirds decreases from tens of thousands to a few hundred.

One of the key assumptions in this study is that fish, upon finding an unbaited hook, do not swim up the longline to find another bait, this assumption is based on the premise that more baited hooks will catch more fish. However we recognize that a direct relationship might not be true. While Murphy (1960) expressed the rate of change of the number of hooked fish as a linear function of the number of baits remaining, Sigler (2000) showed that sablefish Anoplopoma fimbria were adept at locating available baits, even when few remained. Nevertheless, both cases (our study and Sigler's) might be not comparable, Sablefish are good bait predators, probably due to acute olfactory senses (Sigler 2000), while nothing is known about the feeding behaviour of the Argentine ling and the Patagonian toothfish. Sigler (2000) also found that the bait encounter rate 
Table 1. Estimation of economic loss (US\$) for different seabird bycatch rates with and without mitigation measures for the Patagonian toothfish fishery Dissosticus eleginoides and the Argentine ling fishery Genypterus blacodes.

\begin{tabular}{|c|c|c|c|c|c|c|c|c|c|c|}
\hline & \multicolumn{4}{|c|}{ Patagonian toothfish } & \multicolumn{6}{|l|}{ Ling } \\
\hline & $\begin{array}{l}\text { No } \\
\text { deterrents }\end{array}$ & $\begin{array}{l}\text { With } \\
\text { deterrents }\end{array}$ & & & $\begin{array}{l}\text { No } \\
\text { deterrents }\end{array}$ & With deter & ents & & & \\
\hline $\begin{array}{l}\text { Mortality rate (birds/ } \\
\text { I000 hooks) }\end{array}$ & 2 & 0.06 & 0.032 & 0.02 & 1.53 & 0.06 & 0.032 & 0.02 & 0.01 & 0.003 \\
\hline $\begin{array}{l}\text { Total Number of hooks } \\
\text { by fishing trip* }\end{array}$ & 602,640 & 602,640 & 602,640 & 602,640 & $1,557,872$ & $1,557,872$ & $1,557,872$ & $1,557,872$ & $1,557,872$ & $1,557,872$ \\
\hline $\begin{array}{l}\text { Number of Mortalities } \\
\text { by fishing trip }\end{array}$ & 1,205 & 36 & 19 & 12 & 2,384 & 93 & 50 & 31 & 16 & 5 \\
\hline $\begin{array}{l}\text { Number of Lost Baits } \\
\text { by fishing trip }\end{array}$ & 6,026 & 181 & 96 & 60 & 11,918 & 467 & 249 & 156 & 78 & 23 \\
\hline Weight of Bait (gr) \# & 100 & 100 & 100 & 100 & 100 & 100 & 100 & 100 & 100 & 100 \\
\hline $\begin{array}{l}\text { Weight of Lost Bait } \\
\text { by fishing trip (ton) }\end{array}$ & 0.6026 & 0.0181 & 0.0096 & 0.0060 & 1.1918 & 0.0467 & 0.0249 & 0.0156 & 0.0078 & 0.0023 \\
\hline Cost of Bait (US\$/ton) \# & 1,800 & 1,800 & 1,800 & 1,800 & 1,800 & 1,800 & 1,800 & 1,800 & 1,800 & 1,800 \\
\hline $\begin{array}{l}\text { Cost of Lost Bait by } \\
\text { fishing trip (US\$) }\end{array}$ & 1,085 & 32.5 & $17 \cdot 4$ & 10.9 & 2,145 & 84.1 & $44 \cdot 9$ & 28.0 & 14.0 & 4.2 \\
\hline $\begin{array}{l}\text { Processed Catch by } \\
\text { fishing trip (gr/hook) \# }\end{array}$ & 267 & 267 & 267 & 267 & 797 & 797 & 797 & 797 & 797 & 797 \\
\hline $\begin{array}{l}\text { Weight of Lost Fish by } \\
\text { fishing trip (ton) }\end{array}$ & 1.61 & 0.05 & 0.03 & 0.02 & $9 \cdot 50$ & 0.37 & 0.20 & 0.12 & 0.06 & 0.02 \\
\hline Value of Fish (US\$/ton) \# & 18,000 & 18,000 & 18,000 & 18,000 & 4,800 & 4,800 & 4,800 & 4,800 & 4,800 & 4,800 \\
\hline $\begin{array}{l}\text { Value of Lost Fish by } \\
\text { fishing trip (US\$) }\end{array}$ & 28,963 & 869 & 463 & 290 & 45,592 & 1,788 & 954 & 596 & 298 & 89 \\
\hline $\begin{array}{l}\text { Total Loss to Company } \\
\text { ( I fishing trip; US\$) }\end{array}$ & 30,048 & 901 & 481 & 300 & 47,738 & 1,872 & 998 & 624 & 312 & 94 \\
\hline $\begin{array}{l}\text { Total Loss to Company } \\
\text { (10 years; US\$) }\end{array}$ & $1,502,382$ & 45,071 & 24,038 & 15,024 & $2,386,881$ & 93,603 & 49,922 & 31,201 & 15,601 & 4,680 \\
\hline $\begin{array}{l}\text { Total Loss for conservation } \\
\text { (seabirds killed in 1o years) }\end{array}$ & 60,264 & 1,808 & 964 & 603 & 119,177 & 4,674 & 2,493 & 1558 & 779 & 234 \\
\hline
\end{tabular}

${ }^{*}$ The average number of hooks deployed during the study period reported by the company. ${ }^{*}$ considering each bird steals four baits and dies on the fifth attempt. \# reported by the company for 2005 . 
decreased with soak time, and in the Argentinean longline fisheries lines were left in the water for up to 16 hours, while in sablefish were up to 7 hours.

Because bird mortality rates vary throughout the year, between fishing areas and seabird densities, and mitigation measures are fishery-dependent, it is necessary to find a quick solution that is accepted by the companies. Economics is a clear incentive to increase or maintain current income and/or avoid reductions in profits. This model can be developed for any fishery, using cost of bait, fishing efficiency and seabird mortality rates. Changes in mortality rates due to fishery, season, fishing ground, etc, can be easily changed having basic data such as CPUE, bait used, fishing effort and the price of bait and fish. Our estimation of $1 \%$ bait loss to birds is very conservative, considering that other studies suggest this figure is closer to $20 \%$ (Løkkeborg 2001). Estimations in this research were made jointly with fishing companies, and during normal commercial fishing operations. For the effect of comparison we have used the same fishing effort for all estimated mortality rates, but both variables can be easily changed and calculations can be made, changing rates, introducing new measures, or variables that can influence mortality rates. It is important to continue this line of research to obtain field data that complete the picture within each fishery. It is also absolutely necessary to continue with training programmes for crew members, ensuring the right use of deterrents, continuing trials with other deterrents and continued monitoring of bird mortality by trained observers.

\section{Acknowledgements}

This research was funded by the Wildlife Conservation Society and Universidad Nacional de la Patagonia Austral. We thank Argenova S.A. for data and institutional support. We also thank Graham Robertson, Oliver Yates and three anonymous reviewers for their valuable comments on the manuscript.

\section{References}

BirdLife International (2004) Tracking ocean wanderers: the global distribution of albatrosses and petrels. Cambridge, UK: BirdLife International.

Brothers, N. P., Cooper, J. and Løkkeborg, S. (1999) The incidental catch of seabirds by longline fisheries worldwide review and technical guidelines for mitigation. Rome: FAO. (FAO Fisheries Circular 937).

Bull, L. S. (2007) Reducing seabird bycatch in longline, trawl and gillnet fisheries. Fish Fish. 8: 31-56.

Croxall, J. P., Butchart, S. H. M., Lascelles, B., Stattersfield, A. J., Sullivan, B., Symes, A. and Taylor, P. (2012) Seabird conservation status, threats and priority actions: a global assessment. Bird Conserv. Int. 22: 1-34.

Dietrich, K. S., Melvin, E. F. and Conquest, L. (2008) Integrated weight longlines with paired streamer lines - Best practice to prevent seabird bycatch in demersal longline fisheries. Biol. Conserv. 141: 1793-1805.

Dulvy, N. K., Baum, J. K., Clarke, S., Compagno, L. J. V., Cortés, E., Domingo, A., Fordham, S., Fowler, S., Francis, M. P., Gibson, C., Martinez, J., Musick, J. A., Soldo, A., Stevens, J. D. and Valenti, S.
(2008) You can swim but you can't hide: the global status and conservation of oceanic pelagic sharks and rays. Aquat. Conserv. Mar. Freshw. Ecosyst. 18: 459-482.

Favero, M., Khatchikian, C., Arias, A., Silva, M. P., Cañete, G. and Mariano-Jelicich, R. (2003) Estimates of seabird by-catch along the Patagonian Shelf by Argentine Longline Fishing Vessels, 1999-2001. Bird Conserv. Int. 13: 273-281.

Gales, R. (1998) Albatross populations: Status and threats. Pp. $20-45$ in G. Robertson and R. Gales, eds. Albatross biology and conservation. Chipping Norton, UK: Surrey Beatty and Sons.

Gandini, P. and Frere, E. (2001) The Argentinean longline fisheries. Pp. $25-27$ in S. J. Baird, ed. Report on the international fishers forum on solving the incidental capture of seabirds in longline fisheries. Wellington, New Zealand: Department of Conservation.

Gandini, P. and Frere, E. (2006) Seabird mortality pattern in the Argentinean longline fishery. Fish. Bull. 104: 482-485.

Gómez Laich, A., Favero, M., MarianoJelicich, R., Blanco, G., Cañete, G., Arias, A., Silva Rodríguez, P. and Brachetta, $\mathrm{H}$. 
(2006) Environmental and operational variability affecting the mortality of Blackbrowed albatrosses associated with longliners in Argentina. Emu 106: 21-28.

Lewison, R. L., Crowder, L. B., Read, A. J. and Freeman, S. A. (2004) Understanding impacts of fisheries bycatch on marine megafauna. Trends Ecol. Evol. 19: 598-604.

Løkkeborg, S. (2001) Reducing seabird bycatch in longline fisheries by means of birds-scaring lines and underwater setting. Pp. 33-41 in E. Melvin and J. Parrish, eds. Seabird bycatch. Trends, roadblocks and solutions. Fairbanks, Alaska: University of Alaska. (Sea Grant, AK- SG- OI-OI).

Løkkeborg, S. (2008) Review and assessment of mitigation measures to reduce incidental catch of seabirds in longline, trawl and gillnet fisheries. Rome, Italy: FAO. (FAO Fisheries and Aquaculture Circular 1040).

Løkkeborg, S. and Robertson, G. (2002) Seabird and longline interactions: effects of a bird scaring streamer line and line shooter on the incidental capture of Northern fulmars Fulmarus glacialis. Biol. Conserv. 106: 359-364.

Melvin, E. F. and Parrish, J. (2001) Seabird bycatch. Trends, roadblocks and solutions. Fairbanks, Alaska: University of Alaska. (Sea Grant, AK- SG- OI-OI).

Melvin, E. F., Parrish, J. K., Dietrich, K. S. and Hamel, O. S. (2001) Solutions to seabird bycatch in Alaska's demersal longline fisheries. Seattle WA: University of Washington. (Washington Sea Grant Program. Project A/FP- 7. WSG-AS OI-OI).
Melvin, E. F., Sullivan, B., Robertson, G. and Wienecke, B. (2004) A review of the effectiveness of streamer lines as a seabird bycatch mitigation technique in longline fisheries and CCAMLR streamer line requirements. CCAMLR Sci. 11: 189-201.

Murphy, G. I. (1960) Estimating abundance from longline catches. J. Fish. Res. Board Can. 17: 33-40.

Phillips, R. A., Silk, J. R. D., Croxall, J. P. and Afanasyev, V. (2006) Year-round distribution of white-chinned petrels from South Georgia: Relationships with oceanography and fisheries. Biol. Conserv. 129: 336-347.

Poncet, S., Robertson, G., Phillips, R. A., Lawton, K., Phalan, B., Trathan, P. N. and Croxall, J. P. (2006) Status and distribution of wandering, black-browed and grey headed albatrosses breeding at South Georgia. Polar Biol. 29: 772-781.

Robertson, G. and Gales, R. (1998) Albatross biology and conservation. Chipping Norton, UK: Surrey Beatty \&Sons.

Seco Pon, J. P., Gandini, P. A. and Favero, M. (2007) Effect of longline configuration on seabird mortality in the Argentine semipelagic Kingclip Genypterus blacodes fishery. Fish. Res. 85: 101-105.

Sigler, M. F. (2000) Abundance estimation and capture of sablefish (Anaplopoma fimbria) by longline gear. Can. J. Fish. Aquat. Sci. 57: 1270-1283.

Tasker, M. L., Camphuysen, C. J., Cooper, J., Garthe, S., Montevecchi, W. A. and Blaber, S. J. M. (2000) The impacts of fishing on marine birds. J. Mar. Sci. 57: 531-547.

\section{ESTEBAN FRERE}

Centro de Investigaciones de Puerto Deseado. Universidad Nacional de la Patagonia Austral, CONICET. Wildlife Conservation Society (9050), Santa Cruz Argentina. Global Seabird Programme, BirdLife International.

\section{PATRICIA GANDINI*}

Centro de Investigaciones de Puerto Deseado. Universidad Nacional de la Patagonia Austral, CONICET. Wildlife Conservation Society (9050), Santa Cruz Argentina.

*Author for correspondence; e-mail: pagandini@yahoo.com.ar

Received 29 November 2010; revision accepted 20 April 2011; Published online 26 September 2011 